\title{
Heinous Social Criminals Versus the World of Responsibility
}

\author{
M. H. Saier Jr. • W. W. Sun • J. T. Trevors
}

Received: 18 February 2009 / Accepted: 19 February 2009 / Published online: 24 March 2009

(C) Springer Science + Business Media B.V. 2009

Our point in this editorial is very simple: if the dishonest and corrupt people throughout the world, many of whom have disproportional amounts of financial, political, and social influence, were to behave like moral human beings, then the nations of the world would have the economic resources to remedy the conflicts that cause human and biosphere suffering due to overpopulation, excess resource consumption, and global pollution. Instead of war, unwanted births, starvation, and wasteful consumption, accompanied by bankruptcy, bailouts, and unnecessary pollution, environmental responsibility might become the norm so that righteous actions could be taken. We cite below several instances that cut to the core of our world's problems.

1. Social criminals, especially some politicians and high-ranking businessmen, consume far more than their share of tax and insurance dollars to reinforce their positions and to hide and promote

\footnotetext{
M. H. Saier Jr. $(\bowtie) \cdot$ W. W. Sun

Division of Biological Sciences,

University of California at San Diego,

La Jolla, CA 92093-0116, USA

e-mail: msaier@ucsd.edu

J. T. Trevors

Department of Environmental Biology,

University of Guelph,

Guelph, ON, Canada N1G 2W1

e-mail: jtrevors@uoguelph.ca
}

their illegal activities. Is there a possibility that they can come to act as responsible human beings and contribute positively to humanity? If so, governments will not need to spend trillions of dollars annually enforcing laws, prosecuting these social criminals, and putting behind bars the many other less destructive criminals, many of whom are driven by need. Throughout the world, governments spend more of their tax funds on their prison systems than on social planning programs or education. Do we really need to have so many of our fellow citizens in prisons? Can we not teach moral code as a first priority in our schools? Can we not educate people to recognize that nothing comes for free? We need to accept the necessity of paying taxes to cover the needs of our fellow but down-and-out national and international citizens. After all, it is only the right thing to do, as taught by most of the world's great prophets. If so, tax revenues could be directed towards solving the great problems facing us. We might be able to rescue our planet from a collision course resulting from overpopulation, climate change, ozone depletion, and other forms of environmental disaster.

2. Local, national, and international conflicts create the need for the expenditure of trillions of dollars annually. The actual number is likely not known. Over 3 trillion US dollars are estimated to have already been spent in support of an illegal and unjustified war, based on lies, between the USA 
and Iraq. Another approximately 2 trillion US dollars have been spent on corporate bailouts, also promoted by dishonest and risky business dealings. An unknown amount of money is annually spent to keep prisoners behind bars, many of them petty thieves, while the political, economic, and social criminals, who have created the worst problems our human race has ever had to face, get off scot-free. This money they have squandered could have been used for universal birth control, human rights, personal welfare, public transportation, addressing global climate change, and education. It could have allowed us to preserve and improve our planet for future generations instead of creating waste lands and polluted environments. We fear that the loss of all forms of infrastructure, resulting from the loss of our resource base, might permanently prevent the implementation of informed and responsible action, taken to correct the crimes of the past.

3. As noted above, pollution costs humans their own health as well as the health of our entire biosphere. As pollution increases, the costs to remedy this immense problem only expand. Preventative actions coupled with remedial programs to correct and reverse past damage should be taken seriously - that is where our trillions of dollars should be going. This must happen. Otherwise, we will meet, and may already have met, the point of no return. What is worse, the costs of planetary remediation will continue to increase in spite of the well-intentioned actions of a few. We are convinced that as long as the human population continues to grow, we will not be able to implement meaningful programs for reversal of our past destructive actions. Further, an increase in the human population means more pollution, more ozone depletion, more species extinction, and more land and ocean destruction. Let us use our resources not for destructive purposes but to provide the world's populations with the necessities of life. And only then can we really do something about the consequences of our numbers on the planet. It is estimated that to provide the entire population with family planning services would cost the developed countries of the world a mere $30-40$ billion dollars, not the trillions that are yearly being spent because of greed, dishonesty, and a lack of social conscience.
Conservation and universal birth choice availability are our best investments. Let us spend available funds where, and only where, they are most needed.

Are the idealist goals suggested here attainable? It all comes down to the basic question: Can proper nurture conquer our supposedly innate selfish ambitions which may have served us beneficially as an evolving species over the past several million years? Before we can respond with an encouraging "YES," we will need to understand Human Nature as well as the Nature/Nurture argument. What is responsible for greed, selfishness, and corruptive behavior in people who already have everything they could want? Is it their built-in, genetically encoded temperaments, or is it a reflection of the value systems they have gained due to their upbringings? Why are some people more giving, more caring of others, and more concerned about the future than others? To answer these questions is no easy task. In fact, we have no definitive answers as to the origins of greed versus philanthropy in humans. Clearly, these traits can change in individuals over their lifetimes since at the ends of the lives of many cut-throat industrialists, these people change their actions and contribute appreciable sums of the shady money they have acquired to benefit causes that attempt to help others. We do know that behavioral features can be inherited, both in humans and in other animals. If we are to achieve governmental and social responsibility, people everywhere will have to reject their selfish selfcentered actions and care more about the "non-self." Only then can the movement toward humanism, rationality, and environmental responsibility be expected to become a reality. Only then would we have a chance to make this world a sustainable better place. Moreover, even people whose hearts are in the right place often find themselves "too busy" to take the time required to reflect on the choices they have made in the past and to consider how they might change in order to make this world a better place. Thus success will require ACTIVE, not PASSIVE thought and participation.

We all thus need to consider, both from genetic and philosophical standpoints, what may be required to allow the human species to live in harmony with Nature rather than destroying her. We hope there is a way to entice or compel the economic, social, and 
political thugs to join the rest of intelligent society. There must be a way to have EVERYONE behave socially and environmentally responsibly. We might consider resorting to a reward system, to ego satisfaction for proper action, and to severe punitive measures when actions are governed by selfish motives alone. No one should be allowed to pursue greedy, dysfunctional, and corrupt lives at the expense of the health, freedoms, and welfare of other people and species. All we need is for everyone to act in the interests of others. And to accomplish this task is merely to convince the greedy minority that the welfare of the majority must be taken into account in considering any action to be taken. Are we ready to live and teach social and planetary responsibility? Let us hope so. 